\title{
CHILD LABOR IN SOUTHERN INDUSTRY
}

\author{
By A. J. McKelway,
} Assistant Secretary of the National Child Labor Committee.

For a Southern man to criticise the Sonth before a Northern audience is treason; to defend the South is almost an instinct. But if he can throw the blame for anything that is wrong upon New England he may thereby reconcile sentiment and conscience. It is an orthodox introduction, therefore, to say that the invention of a New England pedagogue, a hundred years ago, is the real cause of the crusade in which we are all engaged. That invention changed the face of the industrial and political world. To Eli Whitney's cotton gin may be traced directly the abandonment of manufacturing in the South and the practical monopoly of the cotton growing industry by the South, the development of African slavery from a patriarchal into a commercial institution, the clash between the systems of slave labor and free, the resulting War between the States, and the system of child labor which has been the special curse of the cotton milling industry for a hundred years, first in England, then in New England and later, with the resumption of manufacturing by the South, has become the curse of the Southern cotton mill. Consider these clearly related facts: Ten years before that invention the South shipped I,200 pounds of cotton to England. Last year the South produced $6,500,000,000$ pounds. The first full cargo of cotton shipped to England, shortly after that invention, was seized on the ground that so much cotton could not be produced in the United States. A hundred years ago the South was manufacturing more goods and a greater variety of them than New England; Southern states were vainly protesting against the British and New England slave trade and the extension of slavery; a physician of Leeds, England, had just put on 'record his historic protest against the niggardliness of the hospital authorities in not

[430] 
furnishing enough supports for the bent bones of the deformed children of the cotton mills, and Eli Whitney was receiving his royalty of two shillings sixpence upon each saw of his historic gin. Of course the invention was also a great beneficence. It has made clothing so cheap that the Hong Kong coolie, on a wage scale of three cents a day, may cover his nakedness. But it gave us the slavery problem and has bequeathed to us the negro problem of the South and the child labor problem of the manufacturing states of both Europe and America.

And now the South is again becoming a manufacturing section. In I 900 the value of her manufactured products surpassed that of her agricultural. And it happens that the manufacture of cotton is her characteristic and commanding industry. In 1880 there were 667,000 spindles in Southern mills. In 1900 there were over 7,000,000. In I904 there were twice as many cotton manufacturing establishments in the South as in 1900 . In the two Carolinas the number of spindles has more than doubled in the last six years. But just as there so long hung over the cotton field the pall of negro slavery, so there hangs to-day over the cotton mill the shadow of child slavery. The conscience of the world revolted against man-stealing and man enslavement. But the enslavement of children touches a deeper chord. One of our eloquent phrase makers has spoken of the great smoke-stacks of our flourishing mills as "flaunting their banners of industry against the sky." But when one thinks of the thousands of young lives that are imprisoned within those mills, toiling from daylight to dark or from dark to daylight, an older figure of speech comes to mind-"And the smoke of their torment ascendeth"shall it be "forever"?

It may be broadly stated that there would be no child labor problem to speak of in the South to-day except for the cotton mill, and this industry is centered in the piedmont section of four cotton growing states, North and South Carolina, Georgia and Alabama. It is necessary to discriminate between these states and others of the South as to the extent of the child labor evil, and within these states, as to the character of the work done by children. The South is still mainly an agricultural section. Among those under sixteen years of age, counted by the census makers as engaged in "gainful occupations," by far the greatest number are at work on the farm, under the eye of their parents, although by the operation 
of the tenant system their wages are counted in the sum total for the family. But this is the kind of child labor that is not only not hurtful, but may be beneficial in the direction of physical health and development. The negroes are not employed in the cotton mills and their children may therefore be excluded from the factory problems. Other manufacturing industries make no appreciable demand for the labor of the children. The furniture factories of North Carolina that sell their finished product at Grand Rapids, Michigan, are practically unanimous in their belief and practice that no child under fourteen years of age should be at work in a factory. The evil exists to some extent in the tobacco factories, to no extent in the steel and iron works, while the coal mining states have the protection of fairly good laws against the employment of children. The South is too large a section of country and its industries too varied for any sweeping indictments against it in this matter to be other than the fruit of ignorance or prejudice. And it may be easily proved that because child labor has always been the curse of the cotton mill above all other industries it is such an evil in one section of the South. There should be similar discrimination in reviewing the legislation of the Southern states in the matter of child labor. It is comparatively an unimportant matter that Mississippi, with twenty small cotton mills has an ineffective child labor law, or that Louisiana, with ten cotton mills has lately refused to amend its law, or that Florida, with no cotton mills, is as yet innocent of any remedial legislation on this subject. In the South, although there is a general movement and rapid progress in all lines of manufacturing, cotton is still king in both the factory and the field. North Carolina's rural population is still 85 per cent. of the total, and yet North Carolina has more cotton mills, though smaller ones, than any state in the union and South Carolina stands next to Massachusetts in the number of spindles.

It may be said also, that considering the sudden growth of the cotton milling industry and the bad reputation it has always borne in respect to the employment of children, the South has acted with commendable promptness in recognizing the evil and attempting its cure. The very first protest made in England by way of legislation was in 1802, the twelve-hour law of Sir Robert Peel, which had special reference to the cotton factories and woolen mills. Yet, in r816, out of 23,000 factory hands in a given number of English 
mills, I4,000 were under eighteen, while children of six years were employed. In 1833 Lord Shaftesbury showed that the conditions in the cotton mills had not improved, and made this profoundly significant remark that the evil had "spread from the cotton mills" into other industries. It was not until 1848 that child labor in England was limited to five hours a day for children under thirteen, although the law requiring such children to attend school the other half of the day has resulted in practically as much physical deterioration as from continued employment in the mill. It was not until IgO2 that England passed a law raising the minimum age limit for the employment of children to twelve years, while the same year, after only twenty years of experience with the evil, the three manufacturing states of North Carolina, South Carolina and Alabama, fixed the same age limit by law. Massachusetts, with almost ideal conditions at the beginning, so far as this evil was concerned, had gone backward, until as late as 1879 children from eight to eleven years of age were allowed to work from eleven to fourteen hours a day in the cotton mills. It is worthy of note that free trade, including the abolition of the corn laws in England, has been the same encouragement to manufactures there that protection has been for the United States, driving the people from the farm to the factory. In the decade between 1890 and 1900 the employment of children in factories increased 40 per cent., and of these factory children 61.8 per cent. are in the Middle and Southern states.

It may be fairly said, therefore, that the South has acquired this system of child labor from New England just as New England learned it from old England along with other lessons of the cotton milling business. In fact the very machinery of the cotton mill is adapted to child labor. The spinning frame is built for a child of from twelve to fourteen years of age, so that it is hard for an adult worker to do that particular work through having to stoop to the task. I was told not long ago by a leading dealer in cotton mill machinery that a spooler had been recently put upon the market with adjustable legs for small help. While I learned from the same authority that when the cotton mill was erected in India, for the first time in the history of the industry as conducted by modern machinery, the spinning frames were made high enough from the floor for adult workers, India not being sufficiently civilized to employ children.

And even in the South, the North must share responsibility [433] 
for the continuance of this evil. The history of legislation on this subject is interesting. In 1887 Alabama passed a law forbidding any child under fourteen to work more than eight hours a day in a mill. Then came the wonderful development of the industry and a large influx of northern capital to be invested in that industry. Through the influence of the Northern mill-owners of Alabama mills, that law was repealed. Through the same influences, coupled with those of Southern manufacturers, the child labor law proposed in Alabama, through the efforts of Edgar Gardner Murphy, of Montgomery, failed of passage. The agitation following the defeat of that law resulted in the next two years in putting legislation on the statute books of Alabama, North and South Carolina, the effort failing in Georgia, where again there is large Northern interest in Southern mills, while in the Carolinas the mills are owned almost entirely by Southern men. The agitation spread from the South to the North, where there were better laws upon the books, but in many instances miserably poor enforcement. It was this agitation and its beneficent fruits that led Mr. Murphy to sug. gest the formation of a national committee for the consideration of this problem. For it is admittedly a national and not a sectional evil.

Just as the laws of the manufacturing countries of Europe are superior to those of our own country, so those of the North and of the West are superior to those of the South. There must be discrimination, however, as Massachusetts, New York, New Jersey and Illinois, have the same age limit as Maryland, Tennessee and Kentucky, namely, fourteen for those working in factories, while Pennsylvania has an age limit of thirteen. Virginia, North Carolina, South Carolina (after next May), Alabama, Louisiana, Texas and Arkansas, have the same age limit, namely, twelve, as Maine, New Hampshire, Vermont and Rhode Island, while Delaware and Oklahoma stand with Georgia and Florida in fixing no age limit. It should be said, however, that these statements soon are antiquated since there is a strong effort to raise the age limit in Rhode Island and in Pennsylvania just now, and there will be another attempt to fix an age limit by law and not by an agreement of the manufacturers, merely, in Georgia at the next legislative session. ${ }^{1}$

1 Since the above was written, Rhode Island has raised the age limit to thirteen, and provided that it shall be fourteen after January $I$, r907. Pennsylvania has raised the age limit to fourteen, and Delaware has enacted a fourteen-year standard; likewise Vermont. West Virginia, Kansas, Oregon and California.-S. M. L. ED. 
But there is as yet almost no enforcement of the child labor laws in the Southern states. Putting on record the principle of the right of the state to interfere between the parent and the child in this vital matter is as far as most of our states have gone. There is no system of factory inspection, and it is admitted that the laws are as constantly as they can be easily violated. And while the numbers of the toiling children are larger in the North, through the multiplicity of her manufactures, the percentage of child to adult labor is four times as great in the South as in the North. Conditions are bad enough and should not be minimized, lest they be tolerated too long. The evil is even a growing one with the growth of the cotton milling industry. There are 15,000 children under fourteen years of age working in the cotton mills of North Carolina, not less than 60,000 in the South, and it is known that too many of these are under twelve in spite of law and agreements not to employ such. A recent effort to amend the law in North Carolina by raising the age limit from twelve to fourteen for girls and for boys who cannot read and write, was defeated by the representations of the manufacturers that their business would be ruined, one of them stating publicly that 75 per cent. of the spinners in the North Carolina mills were between the ages of twelve and fourteen. The illiteracy of the manufacturing states of the South is largely due to the competition for the life of the child between the school and the mill, with the manufacturer too often, the parent nearly always, and sometimes the child on the side of the mill. The Northern manufacturing states are also falling in the illiteracy scale, Rhode Island, with its twelve year limit unenforced, having become the most illiterate of Northern states. In North Carolina only 25 per cent. of the children of school age in the factory districts attend school and the percentage is sometimes as low as 8 and io per cent.

But the religious and educational forces of the South, with the aid of the enlightened press of the South, may be trusted to put an end to this hideous abuse. In all other points save this, the cotton mill industry of the South is a real beneficence, and is conducted under the best conditions. It is only necessary that the facts shall be carefully investigated, and published, for the demand to become irresistible from the people themselves that the industry must not be built upon the basis of child labor, nor will it be long before the 
will of kind-hearted people will be translated into humane laws that we may again "present a serene front to civilization."

And I would appeal to the people of the North to sweep before their own doors more carefully as the best means of helping us of the South. When Southern visitors to New York City see the size of the little newsboys and are aware of the newsboy law, they are not much impressed with the adequacy of law to protect children. When our Carolina manufacturers visit the Rhode Island cotton mills and find conditions there as bad if not worse than those in their own factories, it is hard for the advocates of the children's cause in the South to plead the better example of the North. In all respects save this one, conditions in the Southern mills are better than they have ever been elsewhere in their industry.

The child is the savior of the race. The child is the harbinger of the Golden Age, when, as it has been pictured to us, the forces of greed and the forces of violence and the forces of cunning shall walk together in peaceful procession, while "A little child shall lead them." In working for the protection of the child from too early toil, with its stunting of the body and dwarfing of the mind and spoiling of the spirit, we are laboring for the building up of the race that is to be. The child labor problem touches many others. But it seems to me that the old darkey summed up the whole philosophy of this movement when he was made to say:

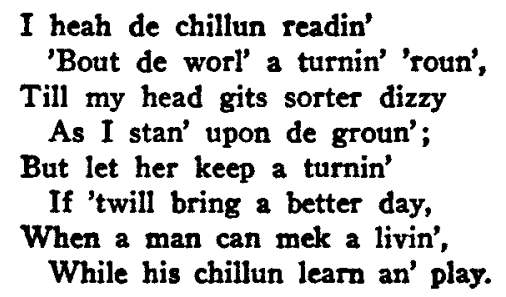

